Politikon, (1999), 26(2), 145-154

\title{
Democracy for a bargain: the 1999 election in KwaZulu-Natal
}

\author{
LAURENCE PIPER*
}

\begin{abstract}
While the IFP/ANC race for first place in KwaZulu-Natal was the closest of any in the country, the 1999 election was both freer and fairer than ever before, and the result was readily accepted by all parties. In short, the 1999 election further consolidated both the institutions and culture of liberal democracy. Importantly, this consolidation was predicated in an understanding reached between the IFP and ANC that, whatever the outcome of the election, they would co-operate in government at both national level and in KwaZuluNatal. In so doing, the stakes of the election were lowered, making a free and fair election not just more affordable but also desirable so as to legitimate future governance. This deal is further confirmation of the trend in KwaZulu-Natal politics away from the ethnically couched confrontational styles of the transition years towards a more ideologically inclusive and co-operative politics. This trend, along with the basic patterns of party affiliation, suggest that KwaZuluNatal is no more unique politically than any other province in South Africa.
\end{abstract}

As a competition amongst political parties for popular support, the 1999 election in KwaZulu-Natal was the closest in the country. The IFP won 41.9 per cent of the provincial ballot to the ANC's 39.38 per cent, in the process confounding the pollsters, ${ }^{1}$ while the DP secured 8.16 per cent, the NNP 3.28 per cent and the MF 2.93 per cent. Critically, unlike in 1994, the results were not shrouded in controversy due to massive intimidation and fraud. Indeed, as an exercise in free and fair electioneering, the election exceeded expectations, reflecting the commitment of political parties to a democratic process. Importantly, this commitment was rooted in a political deal between the ANC and IFP which, represented in the 'peace process', amounted to an agreement that, regardless of the election results, the two parties would govern jointly at national level and in KwaZuluNatal. This lowered the stakes of the election, indeed it encouraged a free and fair election so as to legitimate future governance. Further evidence of the rapprochement cultivated by the ANC since 1994, this deal confirms that the feature which has long distinguished KwaZulu-Natal politics, rivalry between the ANC and IFP, is evolving in a more constructive direction. ${ }^{2}$ 


\section{Political context}

On Friday 14 May 1999 at the Durban City Hall the ANC, led by party deputy-president Jacob Zuma, and the IFP, led by KwaZulu-Natal Premier Lionel Mtshali, signed a code of conduct which embraced (1) free political activity, (2) building a culture of peace and tolerance, (3) a call for impartial and effective policing, and (4) the restraint of party members and supporters from infringing the code. ${ }^{3}$ Addressing a crowd of several thousand afterwards, Zuma and Mtshali said the code was intended to bring to an end the violence that had claimed 14,000 lives in 15 years and facilitate a free and fair election. While the code renewed the ANC/IFP peace process which had begun in the run-up to the 1996 local government elections, it contained nothing not already covered by the Electoral Code of Conduct which political parties, including the ANC and IFP, had publicly signed on 5 May $1999 .{ }^{4}$ The reason for this was that the ANC/IFP code represented more than simply a 'peace deal'. It reflected, and was made possible by, a political understanding between the ANC and IFP that future governance at both national level and in KwaZulu-Natal would be shared between the two parties.

This particular deal must be seen in the context of the ANC's strategy since 1994 of co-operation with the IFP. While the advent of a liberal-democratic constitutional order has facilitated the normalisation of relations between the two parties, ${ }^{5}$ it does not explain their evident rapprochement, represented in the close relationship between Thabo Mbeki and Mangosuthu Buthelezi. Fundamentally, this has materialised because it is in the interests of both parties. First, the ANC has learnt from the transition that the costs of excluding the IFP are high, ${ }^{6}$ while the benefits of including it in government are peace and development. ${ }^{7}$ Second, driven by heavyweights Thabo Mbeki and Jacob Zuma, the ANC has pursued conciliatory tactics with the IFP in the belief that co-operation will emasculate it. This will happen by winning IFP politicians over to the hegemonic perspective of the ANC government, and by blurring the distinction between the ANC and IFP in the eyes of supporters. While the IFP is not unaware of the latter motivation, indeed it is one of the reasons why the party periodically 'rebels' against ANC overtures, co-operation remains attractive as it offers the IFP greater access to power than it would otherwise enjoy. Along with power go the resources crucial for the party's survival and elevated status which is important for key leaders like Buthelezi.

When the peace process was resumed in late March it was presented in the media as national leadership redressing a deterioration in party relations at provincial level. ${ }^{8}$ However, the reality had more to do with the difference between common long-term interests of the ANC and IFP in co-operation, and divergent short-term interests around the election. For the ANC, the belief that it could win KwaZulu-Natal saw it embrace a more aggressive tone which, somewhat unfairly, was associated with new provincial leader S'bu Ndebele. Indeed, with the election now settled, Ndebele has adopted an accommodatory manner consistent with the ANC nationally. Similar dynamics were evident in 
the IFP. In early 1999, KwaZulu-Natal premier Ben Ngubane, a well-respected, competent and moderate IFP leader, was replaced by Lionel Mtshali, an incompetent and hard-line party satrap. Apparently related to the poor performance of the Ngubane's government in respect of education, ${ }^{9}$ the real motivation was Buthelezi's concern to have in place a man who would unquestioningly pursue short-term party interests. ${ }^{10}$ Central here was a more aggressive stance in respect of the ANC, symbolised in Mtshali's announcement to move his office to Ulundi, so as to rekindle anti-ANC sentiment amongst IFP supporters for the election. Given the ANC's own more hard-line posturing, relations deteriorated and reports of violence rose. ${ }^{11}$ Concerned at the consequences for a free and fair election and thus the legitimacy of future governance, Mbeki and Buthelezi stepped in, and the 'peace process' was resumed.

The resumption of talks did not mean that it was only now that the question of future governance was broached. For example, the Mail \& Guardian posited that the deployment of Mtshali as Premier in KwaZulu-Natal was partly to move Ben Ngubane back to national level so that he could play a role in a post-election cabinet. ${ }^{12}$ Certainly speculation as to whether Mbeki had offered Buthelezi the deputy-presidency was already rife, and it seems likely that they already enjoyed an understanding that Buthelezi would hold a senior position in Mbeki's cabinet. Consequently, it is more accurate to read the resumption of the peace process as about the ANC and IFP setting the boundaries within which differing short-term interests over the election could be played out so that the long-term project, co-operative governance, would not be jeopardised. ${ }^{13}$ This tension was complicated by, but not caused by, differences between national and provincial levels of the political parties. In the event, the positive effects of the peace process were felt throughout all aspects of the 1999 election in KwaZulu-Natal.

\section{Administration}

The administration of the election was handled by the Independent Electoral Commission (IEC). Unlike in 1994 when the IEC was seen as ANC-aligned, in 1999 the IEC enjoyed the respect of all parties, confirming the legitimacy of these new political institutions. As Reverend Chris Mzoneli, IEC Provincial Election Officer pointed out, the commitment of parties to a free and fair election had the biggest impact on the positive nature of the event. ${ }^{14}$ While the ANC/IFP peace pact did not remove local tensions, it prevented them from exploding into violence, and demonstrated the capacity of political parties to restrain party members and supporters when the political will is present. Hence it was no surprise that ECCO received only 60 complaints of infringements of the electoral code of conduct. ${ }^{15}$ Indeed, all observers concurred that the 1999 election was a big improvement on the 1996 local government elections, never mind the 1994 election.

In this much improved context the IEC delivered the election in a reasonably efficient, even-handed and also transparent way. This is not to say the election was without administrative problems. There were some minor problems with 


\section{PIPER}

delimitation and counting, but the most important ones concerned the registration process, the voters' roll and the administration of some polling stations on election day. Faced with a potential 4,691,093 voters, the most of any province, the IEC faced a difficult challenge in ensuring good voter registration. This situation was exacerbated by the fact that the IEC spent very little on voter education. Indeed, it was common cause that voter education was a major weak point in election preparations. ${ }^{16}$ In rural areas of the province voter registration simply did not happen until traditional leaders were involved, although their role was decoupled from the rivalry between political parties unlike in $1994 .{ }^{17}$ Hence, following the final registration drive of March 1999, 3,463,753 or 63.4 per cent (64.1 per cent urban, 63.1 per cent rural) of potential voters had registered, the lowest turnout of any province. ${ }^{18}$

In respect of the voters' roll, many who had registered simply did not appear, or appeared at the wrong voting stations. While the IEC had a mechanism to deal with this, almost all political parties expressed the fear that the IEC would be unable to handle the number of people who wanted to vote but who were not on the lists, and that this might lead to violence. ${ }^{19}$ In the event, the IEC decided to allow people to vote at the polling station at which they had registered, but in many places this degenerated into allowing anyone to vote who could prove they had registered. While the figures involved are still unknown, it seems they are small..$^{20}$ Lastly, the functioning of voting stations on election day ran smoothly with the exception of a minority where presiding officers mismanaged the process. Problems emerged because of the last minute change of regulations concerning the voters' role, because the IEC drew from professions unused to dealing with regulations, ${ }^{21}$ and also because of basic incompetence and/or lack of training. ${ }^{22}$ On the whole though, the administration of the election was far closer to the democratic ideal, as was campaigning in 1999.

\section{Campaigning}

The distinctive features of campaigning in KwaZulu-Natal were rooted in the understanding reached between the ANC and IFP, and the peace pact that flowed from that. For one thing, electioneering was far more peaceful than anticipated. In the three months preceding 2 June less than 50 people died in politically related conflict in KwaZulu-Natal. This was dramatically better than in 1994 when 1,000 were killed over a similar period, and much improved on the monthly average of 38 in $1996 .{ }^{23}$ Further, campaigning happened in many 'no-go areas' for the first time, although the extent of this was limited and the nature of it was diplomatic. For example, when the ANC decided to campaign seriously in rural areas it ensured that it did so with the consent of the traditional leaders as far as possible. ${ }^{24}$ Similar accounts of campaigning in the townships were given by the NNP and the IFP. ${ }^{25}$ Lastly, as will be shown, the nature of the campaigns of the ANC and IFP were influenced by the political understanding between the two parties.

Perhaps the most striking feature of the IFP's campaign was not just that it 
had national and provincial components, but that the national component was so well developed. Despite the fact that the IFP won just 14 per cent of its support outside of KwaZulu-Natal in $1994,{ }^{26}$ Buthelezi embarked on a national tour which saw him visit every province at least twice. The national campaign emphasised Buthelezi's status as a national leader, and the IFP's status as a national party which would be better placed to fight the ANC from inside, rather than outside, government. ${ }^{27}$ Given the dependence on KwaZulu-Natal for votes one would have expected the bulk of IFP resources and effort to go into the provincial campaign, and especially the rural areas, not least as the ANC was campaigning in many of these for the first time. However, while the IFP ran a provincial campaign of unprecedented organisational sophistication, activity in rural areas was disappointing, not least due to a lack of funds. Consequently the IFP was unable to host the number and scale of events it would have liked to, and resorted to initiatives in rural areas like public announcements from vehicles, the effectiveness of which was uncertain. ${ }^{28}$

In contrast, the ANC had a much larger budget and could focus all of its energies on winning KwaZulu-Natal. The seriousness with which the ANC regarded the contest was reflected in the large number of visits by Thabo Mbeki and the way he was used at rallies in former 'no-go areas' like Ndwedwe, Richmond and Ulundi. ${ }^{29}$ Embracing what campaign co-ordinator Senzo Mchunu described as a 'consolidate and advance' strategy, the ANC looked to secure its support in urban areas, before moving on to contest other constituencies, notably rural voters. Indeed, the party ploughed unprecedented energy and resources into campaigning in rural areas, particularly those in the south of the province. ${ }^{30}$ Reinforced by opinion polls which consistently put it ahead in the race, the ANC's campaign was remarkably upbeat and free in its criticisms of the IFP. Hence both the IFP and ANC concentrated on the areas in which they were weak $v i s-a ̀-v i s$ the other, the IFP nationally and the ANC in KwaZulu-Natal, safe in the knowledge that while the outcome of the election would not threaten co-operation in governance, it would impact on the precise nature of that governance.

The DP followed closely the strategy and tactics of the national campaign, pouring most of its resources into historically Indian and conservative white areas, rather than its traditional strongholds. It was the only party to systematically use telephone canvassing, in the belief that this was worth at least 20 per cent of its total vote. ${ }^{31}$ The only way the DP's campaign differed from its national strategy was in the manner in which it characterised its relationship with the provincial ANC. Sharing an antipathy with the ANC towards the 'Ulundi mafia', ${ }^{32}$ the KwaZulu-Natal DP balanced the virulent anti-ANC message of national with an anti-IFP slant too. The remaining parties in KwaZulu-Natal conducted campaigns of far lesser significance. Somewhat mysteriously, given the real threat posed by the DP to its Indian and conservative white support, the NNP emphasised the importance of winning black votes. ${ }^{33}$ In effect, it looked to advance before it had consolidated and paid the price. Furthermore its campaign lacked a clear focus in message and tactics, a problem exacerbated by the 


\section{PIPER}

decentralised manner in which it was run. ${ }^{34}$ The MF, while more clearly focused in 'looking after the Indians' emphasised the role of Rajbansi as a politician who would service his constituency 'All the Way' as the campaign slogan had it. The latter also reflected an attempt by the MF to overcome the tendency of MF voters to vote tactically, and thus turn provincial votes into national votes too. ${ }^{35}$ Finally, the UDM ran a very low-key campaign due to both a lack of funds and organisational weakness, ${ }^{36}$ while the ACDP tended to work on a low key, constituency basis.

\section{The results}

That the 1999 election in KwaZulu-Natal bore the imprint of the ANC/IFP understanding and the peace pact which flowed from it, is reflected both in the results themselves and in the way the parties received them. To begin with, the good percentage poll of 84.9 per cent (see Table 1) confirms the picture of a well run and comparatively free and fair election. This noted, some 700,966 (19.13 per cent) fewer votes were cast in 1999 than in 1994, a fact which affirms both party allegations of the lack of voter education and the exceptional nature of the 1994 election. Also notable is that while registration was slightly higher in urban areas than rural (64.1 per cent to 63.1 per cent), turnout was slightly better in rural areas than urban ( 86.27 per cent to 83.76 per cent), therefore having virtually no impact on the outcome.

Table 1. KwaZulu-Natal 1999 election results

\begin{tabular}{|c|c|c|c|c|c|c|}
\hline \multicolumn{3}{|c|}{ National ballot } & \multicolumn{4}{|c|}{ Provincial ballot } \\
\hline Party & Votes & $\%$ & Party & Votes & $\%$ & Seats \\
\hline IFP & $1,196,924$ & 40.45 & IFP & $1,241,522$ & 41.90 & 34 \\
\hline ANC & $1,176,882$ & 39.78 & ANC & $1,167,094$ & 39.38 & 32 \\
\hline DP & 288,548 & 9.75 & DP & 241,779 & 8.16 & 7 \\
\hline NNP & 117,091 & 3.96 & NNP & 97,077 & 3.28 & 3 \\
\hline ACDP & 53,789 & 1.82 & $\mathrm{MF}$ & 86,770 & 2.93 & 2 \\
\hline MF & 43,025 & 1.45 & ACDP & 53,745 & 1.81 & 1 \\
\hline UDM & 38,075 & 1.29 & UDM & 34,586 & 1.17 & 1 \\
\hline FA & 8,984 & 0.30 & FA & 9.762 & 0.33 & \\
\hline PAC & 8,414 & 0.28 & PAC & 7,654 & 0.26 & \\
\hline FF & 6,041 & 0.20 & $\mathrm{FF}$ & 6,804 & 0.23 & \\
\hline AEB & 5,878 & 0.20 & AEB & 5,801 & 0.20 & \\
\hline AZAPO & 4,525 & 0.15 & AZAPO & 5,052 & 0.17 & \\
\hline AITUP & 3,206 & 0.11 & SOPA & 3,451 & 0.12 & \\
\hline UCDP & 2,670 & 0.09 & MUM & 2,261 & 0.08 & \\
\hline SOPA & 2,658 & 0.09 & & & & \\
\hline GPGP & 1,952 & 0.07 & & & & \\
\hline Total & $2,958,662$ & 100 & & $2,963,358$ & 100 & 80 \\
\hline Percentage & 84.8 & & & 84.9 & & \\
\hline
\end{tabular}


Contrary to the opinion polls, the IFP remained the largest party in KwaZuluNatal although with a significant reduction from its 50.3 per cent of 1994 . As importantly, the comparatively free and fair nature of the election meant that this outcome was not called into question. The IFP's performance pushed it into third place nationally, with some 87 per cent of the party's support coming from KwaZulu-Natal, slightly more than in 1994. In this sense then, the IFP's national campaign was a failure. If the IFP is largely a provincial party, then it remains largely a party of rural black people. Some 65.98 per cent of rural voters supported it, constituting 76.45 per cent of its total support in KwaZulu-Natal. Interestingly, this is less than in the 1996 local government elections where the IFP secured 77.35 per cent of the rural vote, constituting 83 per cent of its total vote. ${ }^{37}$ Mostly this reflects that the IFP has lost rural votes to the ANC explaining its overall decline since 1994, but it also reflects that the IFP did slightly better in urban areas receiving 19.17 per cent of the urban vote compared to 14.6 per cent in 1996. As argued below, this extra 5 per cent were mostly white voters voting tactically for the IFP provincially and NNP, possibly the DP, nationally, a trend very similar to $1994 .^{38}$

The IFP's losses were the ANC's gains as the two jostled for the status of KwaZulu-Natal's biggest party. In the end the ANC lost the race by 2.52 per cent, but scored a moral victory by making significant inroads into the IFP's rural support. Indeed the ANC won 27.54 per cent of the rural vote compared to just 17 per cent in 1996, and the rural component of the total ANC vote rose from 24.66 per cent in 1996 to 33.4 per cent in 1999. ANC gains were most remarkable in the south of the province where it secured some 43.7 per cent of the vote, less than 5 per cent adrift of the IFP. For instance in the Ilembe Regional Council, the rural areas surrounding Durban, the IFP pipped the ANC by some 390 votes out of a possible 177,664; and in the Ugu Regional Council, the rural areas on the south coast, the ANC improved from a showing of 17.1 per cent in 1996 to 44.25 per cent in 1999. To some extent this swing can be attributed to the fact that it was in these areas that the ANC campaigned most vigorously, but this begs the question of why it was easier to campaign here. The most likely answers include the distance from the heartland of the IFP both geographically and historically. Notably though, the ANC also made gains in the north of the province of between 5 and 10 per cent for each regional council which confirms that there is no inherent reason why rural Zulu people will not support the ANC.

In addition to the swing in the rural vote, the other significant trend of the 1999 election in KwaZulu-Natal was the reorganisation of the 'opposition' vote. While the ANC and IFP may have struggled vigorously against each other, they kept the same percentage of the overall vote as in 1994 (81.28 per cent), while the other parties shared the remainder. The only difference this time was the collapse of the NNP and the rise of the DP, exactly the same trend as elsewhere in South Africa. Where the NNP secured 11.2 per cent in 1994 and 12.69 per cent in 1996, it dipped dramatically to 3.28 per cent in 1999 ; conversely the DP rose from 2.2 per cent in 1994 , to 3.3 per cent in 1996 , to 8.16 per cent. The 
other beneficiary of the decline of the NNP was the MF which rose slightly from its 1.3 per cent in 1994 to 2.93 per cent in 1999. An examination of the returns by polling district revealed that many areas which used to support the NNP, historically poorer white and historically Indian areas, now endorsed the DP before any other party. ${ }^{39}$

This shift probably had much to do with perceptions about the effectiveness of opposition to government, hence the tactical voting evident between the national and the provincial ballots. For instance, the IFP and the MF both did better provincially than nationally. The IFP gained 44,598 votes or 3.5 per cent in its total provincial support, and the MF 43,745 or 50.4 per cent in its total support. Conversely, the DP gained 46,729 or 16.26 per cent on the national ballot, and the NNP gained 20,014 or 17.1 per cent. An examination of the returns for the historically Indian areas of Chatsworth and Phoenix suggests that half of all MF voters in the province split their vote and supported the DP and NNP on the national ballot, but especially the DP. Similarly, the returns for historically white areas suggest some modest vote-splitting in favour of the NNP nationally and IFP provincially.

\section{Conclusion}

The 1999 election in KwaZulu-Natal was a great advance in the consolidation of democracy, primarily because the dominant political parties in the province wanted it to be. Not only was the legitimacy of democratic institutions affirmed, but important gains were made in respect of extending and deepening values like tolerance and freedom of speech. That is not to say significant problems do not linger on, they do. Nevertheless, the election demonstrated that where there is a political will, there is a peaceful way. This movement towards democracy is also significant in that it reinforces the return of KwaZulu-Natal politics back into the South African mainstream. This applies in respect of degrees of peace and tolerance, but also in respect of the fundamental shape of political allegiances. If one considers the IFP and ANC together, which given their recent rapprochement there is some basis for, then KwaZulu-Natal is no different from the rest of South Africa in its basic patterns of political allegiance. In this province and nationally we have parties in government which represent those who were oppressed under apartheid, and in opposition we have parties representing those who enjoyed some comparative benefit. The legacy of the apartheid political economy (as opposed to simply apartheid racial categories) lingers on.

This granted, the election demonstrated that where KwaZulu-Natal remains unique is in the ongoing rivalry between the IFP and ANC. The results confirm that the divide between the ANC and IFP in KwaZulu-Natal is not ethnic, and while in 1994 and 1996 it was a divide between urban blacks who supported the ANC and rural Zulus who supported the IFP ${ }^{40}$ this is beginning to break down. Not only does this trend reinforce the argument that interest, as much as identity, determines which party voters endorse, ${ }^{41}$ but it affirms the importance of party agency. Indeed, it is the rivalry between the IFP and ANC which is the source 
of all that is substantially different about KwaZulu-Natal politics. ${ }^{42}$ This was illustrated graphically by the fact that the election was freer and fairer because the ANC and IFP had a political understanding that whatever the outcome, they would co-operate in government both nationally and in KwaZulu-Natal. Lastly, though, the 1999 election confirms that since 1994 the ANC/IFP rivalry has moved away from the ethnically couched confrontational styles of the transition years towards a more ideologically inclusive and co-operative politics. ${ }^{43}$ Thus despite the post-election wrangling over the deputy-presidency of South Africa and the premiership of KwaZulu-Natal, the commitment of the ANC and IFP to co-operation in national government and a coalition in KwaZulu-Natal were never in doubt.

\section{Notes and references}

* Laurence Piper is a Lecturer in Political Studies at the University of Natal, Pietermaritzburg.

1. For example, the final Opinion ' 99 poll reported the ANC at 49 per cent in KwaZulu-Natal to the IFP's 17 per cent. Indeed, the highest the IFP ever polled in the eight Opinion ' 99 surveys was 25 per cent; www.idasa.org.za/pos/op99/op99_no30_ kzn.htm

2. See Laurence Piper and Kerri Hampton (1998) "The Decline of "Militant Zulu Nationalism": IFP Politics after 1994', Politikon, 25 (1), pp. 81-101.

3. C. Goodenough (1999) 'The IFP/ANC Code of Conduct', KwaZulu-Natal Briefing, July, pp. 8-9.

4. The Mercury, 6 May 1999. The signing of the Electoral Code of Conduct was the initiative of a KwaZulu-Natal NGO, the Electoral Code of Conduct Commission, set up to monitor the code.

5. There are several reasons for this. First, the issues over which the ANC and IFP fought, leadership of South African resistance politics in the 1980 s, and the process to, and content of, a post-apartheid state in the 1990s, are now settled. Second, both parties have a stake in the new democratic order, with the ANC winning power nationally and the IFP winning in KwaZulu-Natal. Third, confrontational tactics are more costly to pursue with the slow return of law and order, a free press and vigilant civil society, and the co-operative logic of parliamentary politics.

6. Laurence Piper (1999) 'The Politics of Zuluness in the Transition to a Democratic South Africa', PhD thesis, Cambridge University, pp. 99-122.

7. Interview with Yunus Carrim, ANC MP and Chair of the Parliamentary Constitutional Affairs Committee, 27 May 1999.

8. For example see A. Johnston and R.W. Johnson (1998) 'Preparing for Next Year's Big Test', KwaZuluNatal Briefing, March, pp. 22-4.

9. The Witness, 23 January 1999.

10. For example, rumours emerged over the IFP's attempts to influence the allocation of Durban casino licenses to a consortium which included a major IFP funder, maverick British millionaire John Aspinall. Indeed, shortly after assuming office Mtshali appropriated the responsibility for casino licenses from moderate IFP MEC, Peter Miller (interview with Peter Miller, MEC for Finance and Local Government and Housing, 14 April 1999).

11. Sunday Times, 16 May 1999.

12. Electronic Mail \& Guardian, 5 March 1999.

13. A good example of this was the way in which the peace process was not derailed by the discovery of an old IFP arms cache on 11 May, some three days before the signing of the code of conduct. Supplied by the apartheid state, and intended for the arming of IFP members as part of the party's anti-election campaign of early 1994, the arms cache weighed seven tons, making it the largest ever in South Africa's history. Importantly, though, the weapons had remained concealed since the 1994 election and were only excavated when IFP MPP Philip Powell, who had been involved in the military training of IFP members prior to 1994, led the police to the site. Under investigation by the Office of the Director for Public Prosecutions, Mr Powell exposed the cache, apparently in exchange for amnesty from prosecution for gun-running.

14. Interview with Reverend Chris Mzoneli, IEC provincial election officer, 24 June 1999.

15. Interview with Fran Fearnley, Executive Co-ordinator of the ECCO Commission, 18 May 1999.

16. Interviews with Roger Burrows, DP provincial leader, 13 May 1999; Senzo Mchunu, African National 


\section{PIPER}

Congress provincial elections co-ordinator, 18 May 1999; Chris van der Bergh, NNP provincial campaign manager, 27 May 1999; Philip Powell, IFP provincial campaign committee member, 21 June 1999; Chris Mzoneli, IEC provincial election officer, 24 June 1999.

17. Piper (1999), op. cit., p. 119.

18. Independent Electoral Commission (IEC) website; www2.elections.org.za/main_reg.html

19. Interviews with Roger Burrows, DP provincial leader, 13 May 1999; Senzo M $\overline{c h u n u}$, African National Congress provincial elections co-ordinator, 18 May 1999; Chris van der Bergh, NNP provincial campaign manager, 27 May 1999; Philip Powell, IFP provincial campaign committee member, 21 June 1999.

20. Interview with Mawethu Mosery, KwaZulu-Natal IEC Director of Projects and Liaison, 5 June 1999.

21. Interview with Reverend Chris Mzoneli, IEC provincial election officer, 24 June 1999.

22. Interview with Titi Pitso, KwaZulu-Natal IEC Deputy-Director for Party Liaison and Operational Access, 18 May 1999.

23. All figures are from the Human Rights Committee.

24. Interviews with Senzo Mchunu, ANC provincial election co-ordinator, 18 May 1999, and Yunus Carrim, ANC MPP deployed in Ladysmith for the elections, 27 May 1999.

25. Interview with Val Volker, NP MPP, 15 May 1999; Interview with Philip Powell, IFP MPP, 21 June 1999.

26. Andrew Reynolds (1994) 'The results', in A. Reynolds (ed.) Election '94 South Africa: The Campaigns, Results and Future Prospects, pp. 194-5 (Cape Town: David Philip).

27. Interview with IFP election consultant, Andrew Smith, 13 May 1999.

28. Interviews with Philip Powell, IFP MPP, 21 June 1999, Nicky Lucas, IFP PRO 21 May 1999.

29. The Independent on Saturday, 8 May 1999; Witness, 10 May 1999.

30. Interviews with Senzo Mchunu, ANC provincial election co-ordinator, 18 May 1999; Yunus Carrim, ANC MPP deployed in Ladysmith for the elections, 27 May 1999.

31. Interview with Roger Burrows, DP provincial leader, 13 May 1999.

32. Public comment by Roger Burrows at the multi-party debate at the International Conference Centre hosted by East Coast Radio and the Daily News on 26 April 1999.

33. Interview with Danie Schutte, NNP provincial leader, 15 May 1999.

34. Interview with Chris van der Bergh, NNP provincial campaign manager, 27 May 1999.

35. Interview with Shameen Thankur, MF Women's League head, 19 May 1999.

36. Interview with Lucky Cele, UDM provincial leader, 24 May 1999.

37. According to Bill Johnston the rural nature of IFP support helps explain the poor predictions of the polls both in 1999 and in 1994. Not only do polling companies often under-poll rural areas, but there is a significant 'lie factor' due to fear and ignorance which is exacerbated by bad research methods. See R.W. Johnson (1996) 'The 1994 Election: Outcome and Analysis', in R.W. Johnson and Lawrence Schlemmer (eds), Launching Democracy in South Africa: The First Open Election, April 1994 (New Haven and London: Yale University Press) and KwaZulu-Natal Briefing, July 1999, p. 2.

38. L. Piper and S. Piper (1995) 'Hit and Myth: Zulu Ethnicity and the 1994 Election in KwaZulu-Natal', paper presented to South African Political Studies Association (SAPSA) Conference, University of Stellenbosch, 27-9 September 1995.

39. See results on IEC website, www.elections.org.za

40. Piper (1999), op. cit., pp. 167-86.

41. For example, see Robert Mattes (1995) The Election Book: Judgement and Choice in South Africa's 1994 Election (Cape Town: Idasa); Rupert Taylor and Mark Orkin (1995) 'The Racialisation of Social Scientific Research on South Africa', South African Sociological Review, 7 (2), pp. 43-59; and Jeremy Seekings (1997) 'From the Ballot Box to the Bookshelf: Studies of the 1994 South African General Election', Joumal of Contemporary African Studies, 15 (2), pp. 287-309.

42. Piper (1999), op. cit.

43. Piper and Hampton (1998), op. cit. 